\title{
Sapucaia nut (Lecythis pisonis Cambess) and its by-products: A promising and underutilized source of bioactive compounds. Part I: Nutritional composition and lipid profile
}

\author{
Fernanda Demoliner ${ }^{\mathrm{a}}$, Priscila de Britto Policarpi ${ }^{\mathrm{a}}$, Juliano Carvalho Ramos ${ }^{\mathrm{b}}$, \\ Vera Lúcia Azzolin Frescura Bascuñan ${ }^{\mathrm{b}}$, Roseli Aparecida Ferrari ${ }^{\mathrm{c}}$, Iván Jachmanián ${ }^{\mathrm{d}}$, \\ Alicia de Francisco de Casas ${ }^{\mathrm{e}}$, Lúcio Flavo Lopes Vasconcelos ${ }^{\mathrm{f}}$, Jane Mara Block ${ }^{\mathrm{a} \text {,* }}$

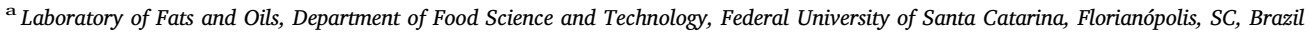 \\ ${ }^{\mathrm{b}}$ Department of Chemistry, Federal University of Santa Catarina, Florianópolis, SC, Brazil \\ ${ }^{\mathrm{c}}$ Institute of Food Technology (ITAL), Campinas, SP, Brazil \\ ${ }^{\mathrm{d}}$ Laboratory of Fats and Oils, Department of Food Science and Technology, University of the Republic (UDELAR), Montevideo, Uruguay \\ ${ }^{\mathrm{e}}$ Laboratory of Cereals, Department of Food Science and Technology, Federal University of Santa Catarina, Florianópolis, SC, Brazil \\ ${ }^{\mathrm{f}}$ Empresa Brasileira de Pesquisa Agropecuária do Meio-Norte (EMBRAPA Meio-Norte), Piauí, Brazil
}

\section{A R T I C L E I N F O}

\section{Keywords:}

Minerals

Selenium

Fatty acids

Triacylglycerol

Tocopherols

Phytosterols

\begin{abstract}
A B S T R A C T
The nutritional composition of the sapucaia nut, cake and shell, the nut and cake minerals content and the lipid profile of the nut oil (fatty acids, tocopherols, phytosterols and triacylglycerols) were determined. The nuts and

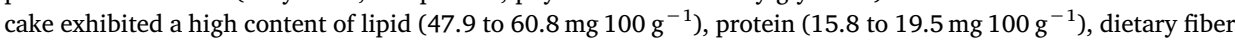

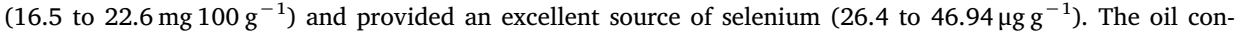
tained a high amount of unsaturated fatty acids ( 39.7 to $45.4 \%$ of oleic and 32.2 to $46.6 \%$ of linoleic acids) and presented a high Oxidative Stability Index $(8.57-12.95 \mathrm{~h})$ indicating the presence of antioxidant compounds in the oil. The major triacylglycerols in the sapucaia oil were LLO, PLO, LOO, POO, OOO, PLL and LLL. The main bioactive lipids identified in the oil were $\gamma$-tocopherol $\left(19.2\right.$ to $28.5 \mathrm{mg} 100 \mathrm{~g}^{-1}$ ) and $\beta$-sitosterol (92.8 to

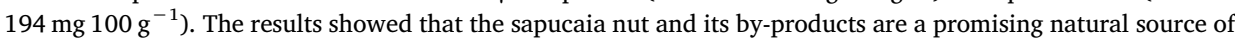
bioactive and nutritional compounds and when present in the diet can contribute to the maintenance of human health. In addition, the nut and by-product represents a promising raw material for the food industry.
\end{abstract}

\section{Introduction}

Nuts such as almonds, cashew nuts, walnuts, pistachios, hazelnuts, pecans, macadamia and Brazil nuts have received special attention from researchers due to their unique combination of nutrients. Studies have confirmed that a daily intake of nuts associated to a healthy diet contributes to the prevention of cardiovascular disease, type II diabetes and cancer (Aune et al., 2016; Nishi et al., 2014; Yang, 2009). The beneficial effects on health probably are due to the synergistic interaction of the bioactive constituents present in the nuts. Nuts provide large amounts of healthy monounsaturated and polyunsaturated fats which help to regulate blood cholesterol and prevent cardiovascular diseases (Nishi et al., 2014). They are also rich in fiber and phytosterols that contribute to the reduction of the cholesterol re-absorption in the intestine (Robbins, Shin, Shewfelt, Eitenmiller, \& Pegg, 2011; SalasSalvadó, Bulló, Pérez-Heras, \& Ros, 2006; Shahzad et al., 2017). In addition, nuts contain tocopherols (vitamin E), minerals (calcium, iron, zinc, potassium and magnesium), antioxidant minerals (selenium, manganese and copper) and phenolic compounds that may reduce oxidative stress and inflammation (Cardoso, Duarte, Reis, \& Cozzolino, 2017; Colpo et al., 2014; Naozuka, Vieira, Nascimento, \& Oliveira, 2011; Robbins et al., 2011). The low content of sodium and high content of potassium contribute to maintain a normal blood pressure (Ndanuko et al., 2017).

Brazil, due to its size and the existence of different biomes, has one of the largest world reserves of native plant species that have not been fully investigated. Such plants may present significant nutritional and economic potential. Sapucaia nut (Lecythis pisonis Cambess), from the

* Corresponding author at: University of Santa Catarina, Agricultural Science Center, Department of Food Science and Technology, Rodovia Admar Gonzaga, 1346, Itacorubi, CEP: 88034-001 Florianópolis, SC, Brazil.

E-mail addresses: vera.bascunan@ufsc.br (V.L.A.F. Bascuñan), roseliferrari@ital.sp.gov.br (R.A. Ferrari), ijachman@fq.edu.uy (I. Jachmanián), lucio.vasconcelos@embrapa.br (L.F.L. Vasconcelos), jane.block@ufsc.br (J.M. Block). 
botanical family of Lecythidaceae, is a species present in the Amazon region and Atlantic forest, mainly in the states of Amazonas, Pará, Rondonia, Piauí, Pernambuco, Maranhão, Bahia, Espirito Santo, Minas Gerais, and Rio de Janeiro (USDA, 2017; Vallilo, Tavares, AuedPimentel, Campos, \& Moita Neto, 1999). The fruits present a weight between 1 and $2.5 \mathrm{Kg}$ and the average yield of sapucaia nuts per tree is $75 \mathrm{~kg}$. Each fruit contain between 30 and 50 nuts and each nut weighs between 4 and $14 \mathrm{~g}$ (Wickens, 1995). The nuts are rich in proteins, essential fatty acids and minerals (Denadai et al., 2007; Naozuka et al., 2011; Teixeira, Ávila, Ribani, Silveira, \& Ribani, 2017; Teixeira, Ghazani, Corazza, Marangoni, \& Ribani, 2018; Vallilo et al., 1999). Although sapucaia nuts are consumed by the local population, their nutritional and phytochemical compositions are unclear and the economic and socio-cultural potential of the nuts have not been explored. Only a few studies have investigated the chemical composition of sapucaia nuts and its by-products. In addition, since there is a demand for this raw material but it is not produced on a large scale, there is a high extractive potential for sapucaia nut, being possible increase their exploitation.

In this study, the nutritional and phytochemical composition of sapucaia nuts, cake, oil and shell were determined. This knowledge is fundamental for encouraging its sustainable production and consumption by the population. In addition, the exploitation of this oleaginous fruit may help the preservation of the ecosystem and the socioeconomic development of the local population and it is also a promising raw material for the food industry.

\section{Materials and methods}

\subsection{Samples}

Sapucaia nuts (Lecythis pisonis Cambess) were collected from native trees in Teresina - Piauí, Brazil (05 $05^{\prime} 21^{\prime \prime}$ S; $42^{\circ} 48^{\prime} 07^{\prime \prime}$ W; $72 \mathrm{~m}$ of altitude, and average annual temperature and relative humidity of $26.2{ }^{\circ} \mathrm{C}$ and $71 \%$, respectively) and provided by the Brazilian Agricultural Research Corporation (EMBRAPA Meio-Norte) (samples A1, A2 e A3). The sample B1 was collected in Viçosa - Minas Gerais, Brazil $\left(20^{\circ} 45^{\prime} 14^{\prime \prime} \mathrm{S} ; 42^{\circ} 52^{\prime} 53^{\prime \prime} \mathrm{W}\right.$; $648 \mathrm{~m}$ of altitude, and average annual temperature and relative humidity of $18.5^{\circ} \mathrm{C}$ and $66 \%$, respectively) and provided by the Federal University of Viçosa (UFV). All samples (about $600 \mathrm{~g}$ each) were harvested in October 2016.

\subsection{Chemical reagents}

The standards and Rh, Ca, Mg, Cu, Zn, Mn, Se, Na, Sn, Pb, Cd, Cr, Ni, $\mathrm{Al}$ and Mo stock solutions were purchased from Sigma-Aldrich Co. (St. Louis,USA). The fatty acid standards (a mix with 37 components, linolenic acid methyl ester isomer mix, all-cis-7,10,13,16,19-docosapentaenoic acid, linoleic acid and conjugated methyl esters) were purchased from Merck (Darmstadt, Germany). The tocopherols standards, $\alpha$-, $\beta$-, $\gamma$ - and $\delta$-tocopherol, and the phytosterols standards, $\beta$ sitosterol, estigmasterol, campesterol and brassicasterol, were purchased from Merck (Darmstadt, Germany). Nitric acid $(65 \% \mathrm{~m} / \mathrm{m})$ was purchased from Merck (Darmstadt, Germany) and purified by quartz double sub-boiling distillation (Kürner Analysentechnik, Rosenheim, Germany). Solvents of analytical grade were used in the chemical analysis and they were purchased from Vetec Fine Chemicals (Xerem, Brazil) and Sigma-Aldrich Co. (St. Louis, USA).

\subsection{Sample preparation and lipid extraction}

The sapucaia nuts were cracked and the sapucaia oil was obtained using a hydraulic press TE-098 Tecnal ${ }^{\circledast}$ (Sao Paulo, Brazil). The samples were pressed three times and the obtained oil was centrifuged for $10 \mathrm{~min}$ at $4.000 \mathrm{rpm}$. The oil samples were stored in amber vials (flushed with nitrogen) at $-24{ }^{\circ} \mathrm{C}$ for further use in the analyses. The

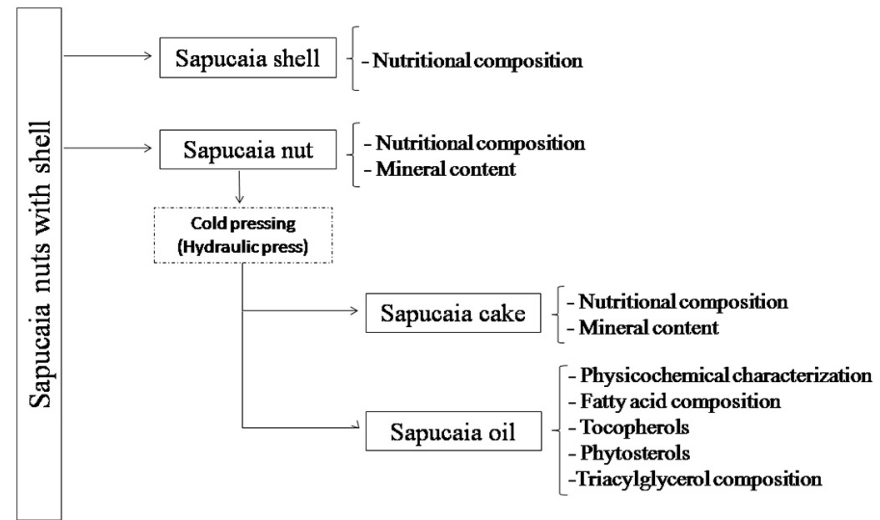

Fig. 1. Analyses carried out on sapucaia nuts, cake, oil and shell.

extraction yield (EY) was calculated according to the equation:

$\mathrm{EY}(\%)=[($ weight of extracted oil $) /($ weight of crushed almonds $)] \times 100$

The physicochemical characterization, fatty acid composition, tocopherol, phytosterol and triacylglycerol content of the extracted oil were determined. The nutritional composition and mineral content of the sapucaia nuts and of the resulting cake generated after pressing of the nuts were determined. Fig. 1 show a schematic diagram of the analyses carried out on sapucaia nuts, cake, oil and shell.

\subsection{Nutritional composition}

The nutritional composition of the sapucaia nut, cake, and shell was performed following the methods recommended by the Association of Official Analytical Chemicals (AOAC, 2005). The moisture content (925.09) was determined by oven-drying the samples at $105^{\circ} \mathrm{C}$ until a constant weight was reached. The ash content (923.03) was determined by incineration at $550 \pm 15^{\circ} \mathrm{C}$. The crude protein content $(\mathrm{N} \times 6.25)$ was estimated by the macro-Kjeldahl method (920.87). The total lipids (920.85) were determined by the Soxhlet extraction method. The total dietary fiber, was analyzed by the enzymatic-gravimetric method (991.43). Total carbohydrates were calculated by difference according to the Eq. (2):

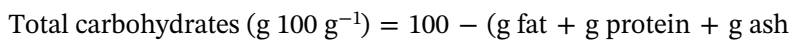

$$
+\mathrm{g} \text { fiber) }
$$

Total energy was calculated according to the Eq. (3):

Energy $\left(\mathrm{kcal} 100 \mathrm{~g}^{-1}\right)=4 \times(\mathrm{g}$ proteins $+\mathrm{g}$ carbohydrates $)+9 \times(\mathrm{g}$ fat $)$

\subsection{Mineral content}

The samples $(0.1 \mathrm{~g})$ were digested using a MLS-1200 Milestone microwave oven (Sorisole, Italy), with $6 \mathrm{~mL}$ of $\mathrm{HNO}_{3}$ and $1 \mathrm{~mL}$ of $\mathrm{H}_{2} \mathrm{O}_{2}$, with the applied power varying from 250 to $600 \mathrm{~W}$ for $25 \mathrm{~min}$ in closed PFA vessels. The digested samples were diluted appropriately with deionized water. Rhodium $\left(10 \mu \mathrm{g} \mathrm{L}^{-1}\right)$ was used as the internal standard for all determinations. External calibration was carried out using aqueous solutions prepared from a multi-element stock standard solution containing all analytes. The elements selenium, calcium, magnesium, manganese, zinc, copper, chrome, nickel, molybdenum, sodium, aluminum, cadmium, tin and lead were determined by inductively coupled plasma mass spectrometry (ICP-MS) using a Perkin Elmer SCIEX, model NexIon 300D (Shelton, USA). The operating parameters of the ICP-MS equipment were: sampling/skimmer cones: platinum; RFpower: $1100 \mathrm{~W}$; signal measurement: continuous; auto lens: on; 
detector voltage: pulse $(1250 \mathrm{v})$ and analog $(-2290 \mathrm{v})$; gas flow rate: main $\left(15.0 \mathrm{~L} \mathrm{~min}^{-1}\right)$ and nebulizes $\left(1.05 \mathrm{~L} \mathrm{~min}^{-1}\right)$. The data on limit of detection (LOD), limit of quantitation (LOQ) and determination coefficients $\left(\mathrm{R}^{2}\right)$ of each mineral are available in Supplementary material (Table S1).

\subsection{Physicochemical characterization of the oil extracted from sapucaia nut}

The physicochemical characteristics of the sapucaia nut oil were determined according to methods of the American Oil Chemists' Society (AOCS, 2004): refractive index (Cc 7-25); relative density (Cc 10a-25); color measurement (Cc 13b-45); smoke point (Cc 9a-48); acid value (Cd 3d-63); peroxide value (Cd 8-53); specific extinction (232 and $270 \mathrm{~nm}$ ) (Ch 5 - 91); $p$-anisidine value (Cd 18-90) and oil stability index (Cd 12b-92).

\subsection{Fatty acid composition}

The fatty acids were determined by the Ce 1a-13 method (AOCS, 2004). The fatty acids methyl esters were prepared following the procedure described by Hartman and Lago (1973). The analyses were performed using a gas chromatograph 3900 Varian $^{\circledR}$ (Palo Alto, USA). The chromatographic conditions were as follows: capillary column (CPSil 88, Chrompack) with $100 \mathrm{~m}$ length, $0.25 \mathrm{~mm}$ inner diameter, and $0.2 \mu \mathrm{m}$ film; and a flame ionization detector (FID). Operating conditions: split of 1:50; detector temperature of $310^{\circ} \mathrm{C}$; injector temperature of $270{ }^{\circ} \mathrm{C}$; oven temperature of $120^{\circ} \mathrm{C} 2 \mathrm{~min}^{-1}, \quad 120-220^{\circ} \mathrm{C}$ $\left(2.2^{\circ} \mathrm{Cmin}^{-1}\right)$ and $220-235^{\circ} \mathrm{C}\left(1.5^{\circ} \mathrm{C} \mathrm{min}^{-1}\right)$, remaining $235^{\circ} \mathrm{C}$ $15 \mathrm{~min}^{-1}$; auxiliary gas (make up gas) nitrogen $\left(30 \mathrm{~mL} \mathrm{~min}^{-1}\right)$; carrier gas: hydrogen $\left(1 \mathrm{~mL} \mathrm{~min}^{-1}\right)$; volume injected of $1 \mu \mathrm{L}$. Each supernatant was injected once into the chromatograph. The qualitative composition was determined by the comparison of peak retention times with the respective standards for fatty acids. The quantitative composition was determined by area normalization and expressed as mass percentage.

\subsection{Tocopherols}

The sample extraction and preparation of standards were carried out according to Panfili, Fratianni, and Irano (2003). Between 0.1 and $1.2 \mathrm{~g}$ of oil was weighed in a $10 \mathrm{~mL}$ flask and the volume was completed with n-hexane. The solution was homogenized on a tube shaker for one minute. The extract was filtered through a Gelman Acrodisc LC13 PVDV $0.45 \mu \mathrm{m}$ pore size syringe filter (PALL Life Sciences, Ann Arbor, USA) before analysis. The tocopherol content of the sapucaia nut oils was determined by HPLC using a Shimadzu Prominence Chromatograph (Shimadzu ${ }^{\circledR}$, Kyoto, Japan). The analysis conditions used were as follows: fluorescence detector at $294 \mathrm{~nm}$ excitation and $326 \mathrm{~nm}$ emission wavelengths; silica column Si-60 Merk (125 nm $\times 4 \mathrm{~nm} \times 5 \mu \mathrm{m})$ with a column temperature of $24^{\circ} \mathrm{C}$ and a flow rate of $1.5 \mathrm{~mL} \mathrm{~min}^{-1}$; mobile phase: n-hexane/ethyl acetate/acetic acid (97.3: 1.8: $0.9 \mathrm{v} / \mathrm{v} / \mathrm{v})$. Peak identification was performed by comparing sample retention times with standards. For analytical quantification, analytical curves from standard compounds were used.

\subsection{Phytosterols}

The analysis of phytosterols was performed according to Bragagnolo and Rodriguez-Amaya (1993). Samples were subjected to direct saponification and the unsaponifiable matter was extracted with hexane and analyzed using a gas chromatograph 3900 Varian $^{\circledR}$ (Palo Alto, USA). The chromatographic conditions for the analysis were: automatic injection $(1 \mu \mathrm{L})$; capillary column (Chrompack CP-Sil 88, $100 \mathrm{~m}$ long, $0,25 \mathrm{~mm}$ internal diameter, $0,20 \mu \mathrm{m}$ de film); split injection (1:50); detector temperatures at $300{ }^{\circ} \mathrm{C}$; injector temperature at were $250{ }^{\circ} \mathrm{C}$; column temperature was initially set at $150{ }^{\circ} \mathrm{C}$ and held for $1 \mathrm{~min}$, then the column was heated at $150-300{ }^{\circ} \mathrm{C}$ at a rate of $10^{\circ} \mathrm{C} \mathrm{min}^{-1}$, and held at $300^{\circ} \mathrm{C}$ for $10 \mathrm{~min}$; auxiliary gas (make up gas) nitrogen $\left(30 \mathrm{~mL} \mathrm{~min}^{-1}\right)$; carrier gas: hydrogen $\left(30 \mathrm{~mL} \mathrm{~min}^{-1}\right)$. Peak identification was performed by comparing the retention times of the samples with the retention times of the standards.

\subsection{Triacylglycerol composition}

The triacylglycerols (TAGs) of the sapucaia nut oil were determined according to the method reported by Segura, Silva, Soares, Gioielli, and Jachmanián (2011), by High-Performance Liquid Chromatography (HPLC) using a chromatograph Shimadzu Prominence 20A (Shimadzu ${ }^{\circledR}$ Corporation, Kyoto, Japan). $5 \mathrm{mg}$ of oil were dissolved in $1 \mathrm{~mL}$ of acetone and mixed by stirring. The chromatographic separation of the compounds was performed using the following HPLC conditions: the injection volume was $1 \mu \mathrm{L}$; detector Shimadzu ELSD-LTII equipped with an evaporative light scattering; two columns Supelcosil ${ }^{\mathrm{TM}} \mathrm{C} 18$ $(25 \mathrm{~cm} \times 4.6 \mathrm{~mm} \times 5 \mu \mathrm{m})$, connected in series and operated at approximately $20^{\circ} \mathrm{C}$; mobile phase was acetone/acetonitrile (1:1) with a flow of $1 \mathrm{~mL} \mathrm{~min}^{-1}$ and an increasing linear gradient of chloroform ( $20 \%$ to $60 \mathrm{~min}$ ). This solvent composition remained constant for $20 \mathrm{~min}$, then it returned to the starting composition at $85 \mathrm{~min}$. Peaks were identified using pure TAG standards and considering the order of elution, according to the corresponding equivalent carbon number (ECN). Two replicate analyses were performed and the average values were reported.

\subsection{Statistical analysis}

All analyses were carried out in duplicate or triplicate and the results were expressed as means \pm standard deviation (SD). The analysis of variance (ANOVA) was carried out and the mean values were compared with Tukey's test considering a 5\% level of significance $(p<0.05)$. The statistical analysis of the results was performed using the software Statistica ${ }^{\circledR} 7.0$ (2008).

\section{Results and discussion}

\subsection{Nutritional composition of sapucaia nut, cake and shell}

Table 1 shows that sapucaia nuts have a high lipid (47.97 to $60.76 \mathrm{~g}$

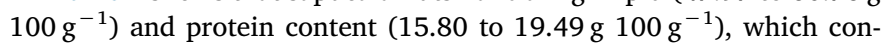
tributes to a high energy value (534.13 to $615.74 \mathrm{kcal} 100 \mathrm{~g}^{-1}$ ). The sample from Minas Gerais (B1) presented a significantly lower $(p<0.05)$ lipid content and a significantly higher $(p<0.05)$ protein content when compared to the samples from Piauí (A1, A2 and A3). The nuts are also rich in dietary fiber and inorganic compounds. Vallilo et al. (1999), Denadai et al. (2007) and Carvalho, Costa, Souza, and Maia (2008) reported similar results for lipid content, protein and ash for sapucaia nuts. The dietary fiber content in the samples of this study was higher than that reported by Denadai et al. (2007), and Carvalho

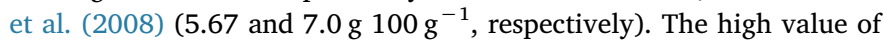
dietary fiber in the nuts may contribute to several health benefits, such as the reduction of the blood cholesterol and of the postprandial glucose response. In addition, the consumption of dietary fibers has been associated to a reduction in the risk of developing coronary heart diseases and diabetes (Salas-Salvadó et al., 2006).

The cake, obtained from the pressing process of sapucaia nuts, contained a high amount of lipids, which is related to the low oil yield (51\%, 45\% 54\% and 30\% for samples A1, A2, A3 and B1, respectively). Costa and Jorge (2012) using the same extraction process reported average oil yields of $59 \%$ for sapucaia nut. Rabadán, Álvarez-Ortí, Gómez, Alvarruiz, and Pardo (2017) reported low yield for pistachio oil obtained by hydraulic press $24.5 \%$. The higher lipid content in the cake obtained from sample B1 may be due to the higher nut moisture content since the extraction efficiency is affected by the sample's temperature 
Table 1

Nutritional composition $\left(\mathrm{g} 100 \mathrm{~g}^{-1}\right.$ ) of sapucaia nut, cake and shell.

\begin{tabular}{|c|c|c|c|c|c|c|c|}
\hline \multirow[t]{2}{*}{ Sample } & \multicolumn{7}{|c|}{ Parameter (dry basis) } \\
\hline & $\begin{array}{l}\text { Moisture } \\
\left(\mathrm{g}_{\left.100 \mathrm{~g}^{-1}\right)}\right.\end{array}$ & Ashes $\left({\left.\mathrm{g} 100 \mathrm{~g}^{-1}\right)}^{-1}\right.$ & Lipids (g $100 \mathrm{~g}^{-1}$ ) & Protein* $\left(\mathrm{g} 100 \mathrm{~g}^{-1}\right)$ & $\begin{array}{l}\text { Total dietary fiber** } \\
\left(\mathrm{g} 100 \mathrm{~g}^{-1}\right)\end{array}$ & $\begin{array}{l}\text { Carbohydrate } \\
\left(\mathrm{g} 100 \mathrm{~g}^{-1}\right)\end{array}$ & $\begin{array}{l}\text { Energy value } \\
\left(\mathrm{kcal} 100 \mathrm{~g}^{-1}\right)\end{array}$ \\
\hline \multicolumn{8}{|l|}{ Nuts } \\
\hline A1 & $4.15 \pm 0.07^{\mathrm{b}}$ & $3.53 \pm 0.20^{\mathrm{a}}$ & $60.76 \pm 0.55^{\mathrm{a}}$ & $15.80 \pm 0.31^{\mathrm{b}}$ & $16.51 \pm 0.87^{\mathrm{a}}$ & $4.90 \pm 0.21^{b}$ & $616.57 \pm 6.64^{\mathrm{a}}$ \\
\hline A2 & $4.31 \pm 0.03^{b}$ & $3.34 \pm 0.20^{\mathrm{a}}$ & $57.49 \pm 0.67^{\mathrm{b}}$ & $15.83 \pm 0.22^{\mathrm{b}}$ & & & \\
\hline A3 & $4.29 \pm 0.09^{\mathrm{b}}$ & $3.36 \pm 0.01^{\mathrm{a}}$ & $59.48 \pm 0.62^{\mathrm{ab}}$ & $16.21 \pm 0.47^{\mathrm{b}}$ & & & \\
\hline B1 & $9.15 \pm 0.11^{\mathrm{a}}$ & $3.34 \pm 0.36^{\mathrm{a}}$ & $47.99 \pm 0.15^{c}$ & $19.49 \pm 0.43^{\mathrm{a}}$ & $22.63 \pm 0.28^{\mathrm{b}}$ & $6.50 \pm 0.04^{\mathrm{a}}$ & $534.13 \pm 3.27^{b}$ \\
\hline \multicolumn{8}{|l|}{ Cake } \\
\hline A1 & $7.61 \pm 0.14^{\mathrm{b}}$ & $5.17 \pm 0.34^{a}$ & $32.41 \pm 2.48^{\mathrm{ab}}$ & $26.78 \pm 1.00^{\mathrm{b}}$ & $31.23 \pm 0.11^{\mathrm{a}}$ & $5.11 \pm 0.13^{\mathrm{a}}$ & $414.31 \pm 1.74^{\mathrm{b}}$ \\
\hline A2 & $6.39 \pm 0.10^{c}$ & $5.02 \pm 0.12^{\mathrm{a}}$ & $31.98 \pm 0.96^{\mathrm{ab}}$ & $26.54 \pm 0.03^{b}$ & & & \\
\hline A3 & $6.68 \pm 0.07^{c}$ & $5.07 \pm 0.09^{\mathrm{a}}$ & $31.36 \pm 0.25^{\mathrm{b}}$ & $26.70 \pm 0.26^{\mathrm{b}}$ & & & \\
\hline B1 & $10.89 \pm 0.10^{\mathrm{a}}$ & $3.35 \pm 0.27^{b}$ & $37.01 \pm 0.47^{\mathrm{a}}$ & $29.67 \pm 0.20^{\mathrm{a}}$ & $27.99 \pm 0.36^{\mathrm{b}}$ & $1.98 \pm 0.04^{\mathrm{b}}$ & $460.43 \pm 3.55^{\mathrm{a}}$ \\
\hline \multicolumn{8}{|l|}{ Shell } \\
\hline A1 & $10.98 \pm 0.07^{\mathrm{b}}$ & $3.36 \pm 0.01^{\mathrm{a}}$ & $0.46 \pm 0.01^{\mathrm{b}}$ & $3.62 \pm 0.17^{\mathrm{a}}$ & $75.22 \pm 1.86^{\mathrm{a}}$ & $17.25 \pm 1.90^{\mathrm{a}}$ & $88.49 \pm 7.49^{\mathrm{a}}$ \\
\hline A2 & $10.31 \pm 0.02^{\mathrm{b}}$ & $3.29 \pm 0.01^{\mathrm{a}}$ & $0.41 \pm 0.05^{\mathrm{b}}$ & $3.82 \pm 0.01^{\mathrm{a}}$ & & & \\
\hline A3 & $10.86 \pm 0.03^{b}$ & $3.17 \pm 0.07^{\mathrm{a}}$ & $0.61 \pm 0.05^{\mathrm{a}}$ & $3.88 \pm 0.08^{\mathrm{a}}$ & & & \\
\hline B1 & $13.44 \pm 0.06^{\mathrm{a}}$ & $2.73 \pm 0.10^{\mathrm{b}}$ & $0.63 \pm 0.01^{\mathrm{a}}$ & $3.99 \pm 0.07^{\mathrm{a}}$ & $80.89 \pm 1.00^{\mathrm{a}}$ & $11.75 \pm 0.83^{\mathrm{b}}$ & $68.64 \pm 3.61^{\mathrm{a}}$ \\
\hline
\end{tabular}

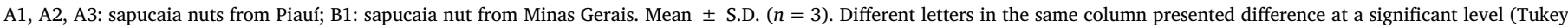
test, $p<0.05$ ).

* Nitrogen conversion factor $=6.25$.

** The fiber analysis for the samples from Piauí were made for a pool of the samples.

and moisture (Rabadán et al., 2017). Moisture, ash, protein and dietary fiber contents of sapucaia cake were higher than those obtained from the nut because the oil separation concentrates the other components in the residual cake. The protein content was significantly higher $(p<0.05)$ for sample B1 when compared to samples A1, A2 and A3. On the other hand, the ash, dietary fiber and carbohydrate content for sample B1 was significantly lower $(p<0.05)$.

Dietary fiber represented the largest fraction of the composition of

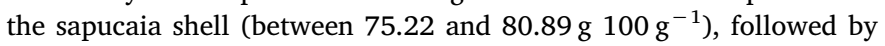

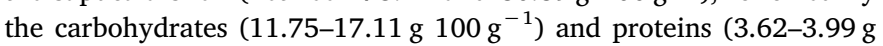
$\left.100 \mathrm{~g}^{-1}\right)$. The ashes were significantly higher $(p<0.05)$ for the sam-

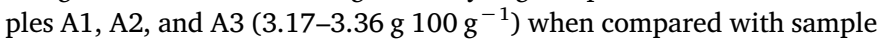
B1 $\left(2.73100 \mathrm{~g}^{-1}\right)$. The lipid content represented the smaller fraction of the sapucaia shell and was significantly higher $(p<0.05)$ for the samples A3 and B1.

The significant differences observed on the nutritional composition of the sapucaia nuts, cakes and shells obtained from different regions may be related to environmental factors, soil composition, geographical location, harvest period and genetic factors (Yada, Huang, \& Lapsley, 2013).

\subsection{Mineral content of sapucaia nuts and cake}

The sapucaia nuts and cake contained 13 mineral elements (Table 2). The selenium (Se) concentration in the nut ranged between 26.4 and $46.9 \mu \mathrm{g} \mathrm{g}^{-1}$ and between 28.7 and $48.5 \mu \mathrm{g} \mathrm{g}^{-1}$ in the cake. The results indicate that the intake of a single sapucaia nut $(2 \mathrm{~g})$ may be sufficient to reach the recommended adult daily intake of selenium ( $55 \mu \mathrm{g} /$ day), not exceeding the Tolerable Upper Intake Level (UL) (Supplementary material Table S2) (FAO/WHO, 2001; Food \& Nutrition Board, 2004). Selenium, as a constituent of selenoproteins, is an essential micronutrient playing an important role in numerous physiological functions such as the conversion of the prohormone thyroxine (T4) to the active thyroid hormone triiodothyronine (T3), and also the conversion of inactive reverse $\mathrm{T} 3$ to diiodothyronine. The antioxidant activity of Se is also related to the prevention of age-related illnesses such as cancer and cardiovascular diseases (Kumar \& Priyadarsini, 2014). Selenium has the ability to increase mercury (Hg) excretion and eliminate reactive oxygen species induced by $\mathrm{Hg}$, indicating a protective action against the $\mathrm{Hg}$ (Sakamoto et al., 2013). A selenium daily intake $<40 \mu \mathrm{g}$ has been considered deficient. The selenium deficiency may lead to Keshan disease (an endemic cardiomyopathy with myocardial insufficiency), cancer and cardiovascular diseases (Roman, Jitaru, \& Barbante, 2014). On the other hand, an intake of $>400 \mu \mathrm{g} /$ day of Se has been associated with toxic effects, including selenose, the symptoms of which are loss of hair and nails, skin lesions and disorders of the nervous system (Roman et al., 2014). Considering the level of Se detected in a single sapucaia nut a daily intake exceeding 8-10 nuts may therefore exceed the toxicity limit for Se.

In other studies, Lemire, Fillion, Guimarães, and Mergler (2010) reported a Se content in the sapucaia nut between 5.01 and $14.36 \mu \mathrm{g} \mathrm{g}^{-1}$. The Brazil nut, which has a content of Se between 0.2 and $512 \mathrm{mg} \mathrm{kg}^{-1}$, is considered the food with the highest content of Se (Silva Júnior et al., 2017).

Sapucaia nuts are also rich in calcium (Ca) and magnesium (Mg). The Supplementary material (Table S2) shows the Recommended Dietary Allowance (RDA) for minerals for adults (19-50 years). Ca and $\mathrm{Mg}$ are important minerals in the diet. The first is related to bone health and protection against bone loss. On the other hand, $\mathrm{Mg}$ is related with activation of enzymatic systems (Fardellone, 2015). Denadai et al. (2007), Carvalho et al. (2012) and Naozuka et al. (2011) reported greater amounts of $\mathrm{Ca}$ and $\mathrm{Mg}$ in sapucaia nut samples from different regions of Brazil (1720 and $2790 \mu \mathrm{g} \mathrm{g}^{-1} ; 1821$ and $3434 \mu \mathrm{g} \mathrm{g}^{-1}$; and 1798 and $3151 \mu \mathrm{g} \mathrm{g}^{-1}$, respectively) when compared to the results of this study. However, smaller amounts for $\mathrm{Ca}\left(880 \mu \mathrm{g} \mathrm{g}^{-1}\right)$ and similar quantities for $\mathrm{Mg}\left(1465 \mu \mathrm{g} \mathrm{g}^{-1}\right)$ were reported by Vallilo et al. (1999) in sapucaia nut.

$\mathrm{Mn}, \mathrm{Zn}$ and $\mathrm{Cu}$ are metals required in trace amounts for alarge number of physiological functions. Mn is a cofactor for many enzymes, including hydrolases, lyases, superoxide dismutase (SOD) and glutamine synthetase (Parmalee \& Aschner, 2016). Zn plays important role in the normal functioning of immune system and acts as ionic signalling in large number of cells (Wani et al., 2017). Cu is an essential cofactor and a structural component of a number of important enzymes which are involved in redox reactions (Scheiber, Mercer, \& Dringen, 2014). Denadai et al. (2007) and Carvalho et al. (2012) reported higher values for $\mathrm{Mn}\left(80.69 \mu \mathrm{g} \mathrm{g}^{-1}, 48 \mu \mathrm{gg}^{-1}\right.$, respectively), $\mathrm{Zn}\left(40.37 \mu \mathrm{g} \mathrm{g}^{-1}\right.$, $44 \mu \mathrm{g} \mathrm{g}^{-1}$, respectively) and $\mathrm{Cu}\left(32.76 \mu \mathrm{g} \mathrm{g}^{-1}, 23 \mu \mathrm{g} \mathrm{g}^{-1}\right.$, respectively) when compared with the results of this study. Naozuka et al. (2011) 


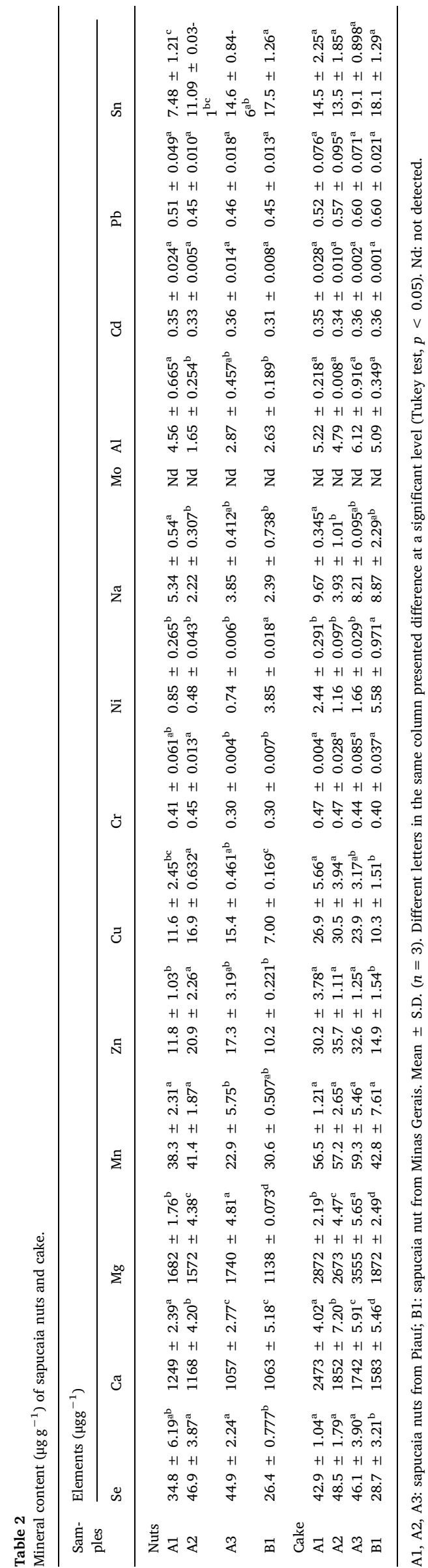

also found higher values for Mn $\left(64.3 \mu \mathrm{g} \mathrm{g}^{-1}\right)$ and $\mathrm{Zn}\left(39.3 \mu \mathrm{g} \mathrm{g}^{-1}\right)$ but reported lower values for $\mathrm{Cu}\left(9.2 \mu \mathrm{g} \mathrm{g}^{-1}\right)$.

It has been reported that chromium ( $\mathrm{Cr}$ ) and nickel $(\mathrm{Ni})$ are related to risk reduction for chronic diseases such as osteoporosis and diabetes. They are also beneficial to central nervous system function and bone development (Nielsen, 2014). The RDA established for $\mathrm{Cr}$ is $35 \mu \mathrm{g} / \mathrm{d}$ and $25 \mu \mathrm{g} / \mathrm{d}$, for male and female, respectively; and for $\mathrm{Ni}$ is $1 \mathrm{mg} /$ day (FAO/WHO, 2001; Food \& Nutrition Board, 2004). Carvalho et al. (2012) reported higher values for $\mathrm{Ni}\left(5 \mu \mathrm{g} \mathrm{g}^{-1}\right)$ in sapucaia nuts when compared to the present study, and the Cr levels were not detected. The concentration of sodium (Na) in samples of sapucaia nut and cake were low (mean of 3.35 and $7.67 \mu \mathrm{g} \mathrm{g}^{-1}$, respectively) considering that the international bodies of nutrition recommend an intake for Na of $1.5 \mathrm{~g}$ / day. Denadai et al. (2007) also detected low levels of $\mathrm{Na}\left(5.8 \mu \mathrm{g} \mathrm{g}^{-1}\right)$ in samples of sapucaia nut.

Toxic and non-essential elements such as aluminum (Al), cadmium $(\mathrm{Cd})$, lead $(\mathrm{Pb})$ and tin $(\mathrm{Sn})$ were also identified in sapucaia nut and cake. According to the Agency for Toxic Substances and Disease Registry, the limit of $\mathrm{Al}$ is $1 \mathrm{mg} \mathrm{kg}^{-1}$ of weight/day (ATSDR, 2017). The maximum level recommended for $\mathrm{Cd}$ is $0,05 \mathrm{mg} \mathrm{kg}^{-1} /$ day and for $\mathrm{Pb}$ in vegetables is $0.2 \mathrm{mg} \mathrm{kg}^{-1}$ (Codex Alimentarius, 1996). There is no recommended limit for the ingestion of Sn. In this study none of the samples exceeded the values considered as toxic by the Agency for Toxic Substances and Disease Registry and Codex Alimentarius Commission. Heavy metals in food derive from several sources such as soil polluted by heavy metals (where they may stay for longer periods because of their higher affinity with organic matter), pesticides and fertilizers (Zang, Wang, Ashraf, Qiu, \& Ali, 2017).

\subsection{Physicochemical analysis of the sapucaia nut oil}

Table 3 shows some characteristics of identity and quality of the sapucaia nut oil. The refraction index (between 1.469 and 1.470 at $20^{\circ} \mathrm{C}$ ) indicated that the oils are rich in unsaturated fatty acids. Density at $20{ }^{\circ} \mathrm{C}$ ranged between 0.88 and $0.92 \mathrm{~g} / \mathrm{cm}^{3}$ and the Lovibond color (30.0-40.0 for yellow units and $0.8-1.0$ for red units) indicated a yellow color for the oil. The oil showed a peroxide value in accordance with the Brazilian National Health Surveillance Agency (ANVISA) for unrefined cold-pressed oils (maximum of $15 \mathrm{mEq} \mathrm{kg}^{-1}$ for virgin oils) (Brazil, 2005). The peroxide value and specific extinction (232 and $270 \mathrm{~nm}$ ) indicated adequate oxidative quality for the oil. The Oxidative Stability Index (OSI) of the sapucaia nut oil was between 8.57 and $12.95 \mathrm{~h}$, which reflects its fatty acid composition and the presence of antioxidant compounds in the oil. The OSI was significantly $(p<0.05)$ higher for samples A1, A2 and A3 when compared to sample B1, due to high oleic acid content. Costa and Jorge (2012) found a higher oxidative stability $(24.89 \mathrm{~h})$ of the sapucaia oil extracted by cold pressing at $100{ }^{\circ} \mathrm{C}$. Teixeira et al. (2017) reported an OSI of $7.18 \mathrm{~h}$ of the sapucaia nut oil extracted by Soxhlet, and $13 \mathrm{~h}$ for sapucaia nut oil extracted by Bligh \& Dyer. Teixeira et al. (2018) reported an OSI of $9.29 \mathrm{~h}\left(110^{\circ} \mathrm{C}\right)$ of the sapucaia nut oil extracted using supercritical $\mathrm{CO}_{2}$. The results obtained in this work were similar for the induction period reported for Brazil nut $(8.24 \mathrm{~h})$, canola $(8.63 \mathrm{~h})$, hazelnut $(8.88 \mathrm{~h})$, pecan (9.87), corn $(9.96 \mathrm{~h})$, and soybean $(12.0 \mathrm{~h})$ oils (Castelo-Branco, Santana, DiSarli, Freitas, \& Torres, 2016). Although there is no established minimum value for the induction period for vegetable oils, the longer the induction period, the greater the oxidative stability of the oil.

\subsection{Fatty acid composition, content of tocopherols and phytosterols in samples of sapucaia oil}

Ten different fatty acid were identified in the sapucaia nut oil. Oleic acid was predominant in the A1, A2 and A3 samples (39.7 to 45.4\%), and linoleic acid in the sample B1 (46.6\%). Among the saturated fatty acids, palmitic and stearic acids were the major fatty acids (11.1-15.2\% and $7.50-8.44 \%$, respectively). The sapucaia nut oil is a source of 
Table 3

Physicochemical characteristics of sapucaia nut oil.

\begin{tabular}{|c|c|c|c|c|}
\hline \multirow[t]{2}{*}{ Parameter } & \multicolumn{4}{|l|}{ Samples } \\
\hline & A1 & $\mathrm{A} 2$ & A3 & B1 \\
\hline Refraction index $\left(20^{\circ} \mathrm{C}\right)$ & $1.469 \pm 0.001^{\mathrm{a}}$ & $1.469 \pm 0.001^{\mathrm{a}}$ & $1.469 \pm 0.001^{\mathrm{a}}$ & $1.470 \pm 0.001^{\mathrm{a}}$ \\
\hline Density $\left(\mathrm{g} / \mathrm{cm}^{3}\right)$ & $0.91 \pm 0.003^{\mathrm{a}}$ & $0.91 \pm 0.001^{\mathrm{a}}$ & $0.92 \pm 0.006^{\mathrm{a}}$ & $0.88 \pm 0.002^{\mathrm{a}}$ \\
\hline Smoke point $\left({ }^{\circ} \mathrm{C}\right)$ & $209.0 \pm 2.83^{\mathrm{b}}$ & $210.5 \pm 0.70^{\mathrm{b}}$ & $210.0 \pm 2.83^{\mathrm{b}}$ & $217.5 \pm 1.77^{\mathrm{a}}$ \\
\hline Acid value (g oleic acid $100 \mathrm{~g}^{-1}$ ) & $0.19 \pm 0.02^{\mathrm{b}}$ & $0.19 \pm 0.01^{\mathrm{b}}$ & $0.20 \pm 0.01^{\mathrm{b}}$ & $0.34 \pm 0.02^{\mathrm{a}}$ \\
\hline Peroxide value $\left(\mathrm{mEq} \mathrm{Kg}{ }^{-1}\right)$ & $1.47 \pm 0.11^{\mathrm{b}}$ & $1.53 \pm 0.44^{\mathrm{b}}$ & $1.60 \pm 0,02^{\mathrm{b}}$ & $2.52 \pm 0.12^{\mathrm{a}}$ \\
\hline Specific extinction - $232 \mathrm{~nm}(\%)$ & $0.74 \pm 0.02^{\mathrm{b}}$ & $0.78 \pm 0.02^{\mathrm{b}}$ & $0.73 \pm 0.02^{\mathrm{b}}$ & $1.46 \pm 0.02^{\mathrm{a}}$ \\
\hline Specific extinction - $270 \mathrm{~nm}(\%)$ & $0.03 \pm 0.01^{\mathrm{b}}$ & $0.07 \pm 0.02^{\mathrm{b}}$ & $0.02 \pm 0.01^{\mathrm{b}}$ & $0.39 \pm 0.01^{\mathrm{a}}$ \\
\hline$p$-Anisidine value & $\mathrm{Nd}$ & $\mathrm{Nd}$ & $\mathrm{Nd}$ & $\mathrm{Nd}$ \\
\hline Oxidative stability index - OSI (h) & $12.95 \pm 0.06^{\mathrm{a}}$ & $12.88 \pm 0.07^{\mathrm{a}}$ & $12.75 \pm 0.22^{\mathrm{a}}$ & $8.57 \pm 0.23^{\mathrm{b}}$ \\
\hline Color Lovibond $\left(5^{1 / 4} \text { in }\right)^{*}$ & $30.0 \mathrm{Y} / 1.0 \mathrm{R}$ & $40.0 \mathrm{Y} / 1.0 \mathrm{R}$ & $30.0 \mathrm{Y} / 1.0 \mathrm{R}$ & $40.0 \mathrm{Y} / 0.8 \mathrm{R}$ \\
\hline
\end{tabular}

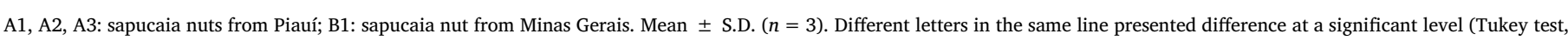
$p<0.05)$. Nd $=$ not detected

$* \mathrm{Y}=$ yellow, $\mathrm{R}=$ red.

unsaturated fatty acids, since it contained an unsaturated ratio between 0.27 and $0.30 \%$. The fatty acid composition of the sapucaia nut oil obtained for samples from Piauí were similar to the results reported by Vallilo et al. (1999) and Costa and Jorge (2012). Similar results obtained for samples from Minas Gerais were reported for Teixeira et al. (2017) and Teixeira et al. (2018) who found oleic acids as major component in sapucaia nut oil, followed by linoleic and palmitic acids. It has been reported that the substitution of dietary saturated fat by oleic acid and/or polyunsaturated fatty acids may reduce the cardiovascular risk, mainly by reducing blood cholesterol levels (Nishi et al., 2014).

The $\gamma$-tocopherol was the main tocopherol identified in sapucaia nut oil, representing from 88 to $95 \%$ of the total content of these compounds. Low concentrationsof $\alpha$ - and $\delta$-tocopherol were also identified.
Anticancer and anti-inflammatory effects have been reported for $\gamma$-tocopherol (Jiang, 2014).

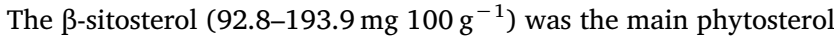
identified in sapucaia nut oil, followed by the stigmasterol ( 9.92 and

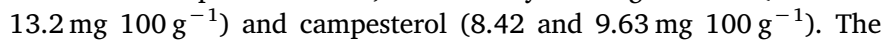
content of stigmasterol and campesterol was significantly greater $(p<0.05)$ in sample B1 (Table 4). The $\beta$-sitosterol is a well-recognized cholesterol-lowering agent (total plasma cholesterol and low-density lipoprotein) (Desai, Dong, \& Miller, 2016). Anti-cancer, anti-inflammatory activities and protection against cardiovascular diseases have been also reported for $\beta$-sitosterol (Desai et al., 2016; Shahzad et al., 2017). $\beta$-sitosterol alone or in combination with other phytosterols (in free or esterified form) is used in a variety of enriched commercial foods such as yoghurt, milk and fruits juice.

Table 4

Fatty acid composition, tocopherols and phytosterols of sapucaia oil.

\begin{tabular}{|c|c|c|c|c|}
\hline \multirow[t]{2}{*}{ Parameter } & \multicolumn{4}{|l|}{ Samples } \\
\hline & $\mathrm{A} 1$ & $\mathrm{~A} 2$ & $\mathrm{~A} 3$ & B1 \\
\hline \multicolumn{5}{|l|}{ Fatty acids (\%) } \\
\hline Myristic acid (C 14:0) & 0.10 & 0.09 & 0.09 & 0.07 \\
\hline Palmitic acid (C 16:0) & 15.2 & 12.9 & 14.4 & 11.1 \\
\hline Palmitoleic acid (C 16:1) & 0.35 & 0.21 & 0.21 & 0.24 \\
\hline Margaric acid (C 17:0) & 0.08 & 0.08 & 0.07 & 0.07 \\
\hline Stearic acid (C 18:0) & 7.93 & 8.44 & 7.91 & 7.50 \\
\hline Oleic acid (C18:1 n9c) & 39.7 & 45.4 & 44.4 & 40.0 \\
\hline Linoleic acid (C 18:2 n6c) & 40.0 & 32.3 & 32.2 & 46.6 \\
\hline$\gamma$-linolenic acid (C 18:3) & 0.27 & 0.26 & 0.27 & 0.22 \\
\hline$\alpha$-Linolenic acid (C 18:3 n3c) & 0.35 & 0.26 & 0.32 & 0.22 \\
\hline Cis-11-eicosenoic acid (C 20:1) & 0.07 & 0.07 & 0.08 & 0.06 \\
\hline Total saturated fatty acids & 23.3 & 21.5 & 22.5 & 18.8 \\
\hline Total monounsaturated fatty acids & 40.1 & 45.7 & 44.7 & 34.2 \\
\hline Total polyunsaturated fatty acids & 36.6 & 32.8 & 32.7 & 47.0 \\
\hline $\mathrm{S} / \mathrm{U}^{*}$ & 0.30 & 0.27 & 0.29 & 0.23 \\
\hline \multicolumn{5}{|l|}{ Tocopherols (mg $100 \mathrm{~g}^{-1}$ ) } \\
\hline$\alpha$-Tocopherol & $1.12 \pm 0.03^{\mathrm{b}}$ & $0.75 \pm 0.09^{b}$ & $1.10 \pm 0.01^{\mathrm{b}}$ & $2.24 \pm 0.16^{\mathrm{a}}$ \\
\hline$\beta$-Tocopherol & $\mathrm{Nd}<0.02^{*}$ & $\mathrm{Nd}<0.02$ & $\mathrm{Nd}<0.02 *$ & $\mathrm{Nd}<0.02$ \\
\hline$\gamma$-Tocopherol & $28.5 \pm 0.49^{\mathrm{a}}$ & $21.2 \pm 0.13^{\mathrm{b}}$ & $26.8 \pm 0.83^{\mathrm{a}}$ & $19.2 \pm 0.17^{\mathrm{b}}$ \\
\hline$\delta$-Tocopherol & $0.28 \pm 0.02^{\mathrm{b}}$ & $0.26 \pm 0.02^{\mathrm{b}}$ & $0.41 \pm 0.01^{\mathrm{a}}$ & $0.43 \pm 0.02^{\mathrm{a}}$ \\
\hline Total tocopherols & $29.9 \pm 0.54^{\mathrm{a}}$ & $22.2 \pm 0.24^{\mathrm{b}}$ & $28.3 \pm 0.85^{\mathrm{a}}$ & $21.8 \pm 0.32^{\mathrm{b}}$ \\
\hline Vitamin E (UI $100 \mathrm{~g}^{-1}$ ) & 6 & 4 & 5 & 5 \\
\hline \multicolumn{5}{|l|}{ Phytosterols (mg $100 \mathrm{~g}^{-1}$ ) } \\
\hline$\beta$-sitosterol & $93.7 \pm 0.78^{c}$ & $101.3 \pm 1.34^{\mathrm{b}}$ & $92.8 \pm 1.49^{c}$ & $193.9 \pm 1.84^{\mathrm{a}}$ \\
\hline Stigmasterol & $11.2 \pm 0.19^{\mathrm{b}}$ & $11.8 \pm 0.36^{\mathrm{b}}$ & $9.92 \pm 0.42^{c}$ & $13.2 \pm 0.09^{\mathrm{a}}$ \\
\hline Campesterol & $8.60 \pm 0.49^{b c}$ & $9.11 \pm 0.32^{\mathrm{ab}}$ & $8.42 \pm 0.28^{\mathrm{bc}}$ & $9.63 \pm 0.26^{\mathrm{a}}$ \\
\hline Brassicasterol & $\mathrm{Nd}<1.50$ & $\mathrm{Nd}<1.50$ & $\mathrm{Nd}<1.50$ & $\mathrm{Nd}<1.50$ \\
\hline
\end{tabular}

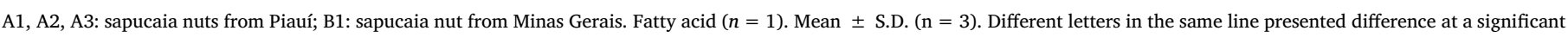
level (Tukey test, $p<0.05$ ). $\mathrm{Nd}=$ not detected.

* S/U: Saturated to unsaturated ratio. 
Table 5

Triacylglyceride (TAG) composition of sapucaia oil.

\begin{tabular}{|c|c|c|c|c|c|}
\hline \multirow[t]{2}{*}{ TAGs } & \multirow[t]{2}{*}{ ECN } & \multicolumn{4}{|l|}{ Samples (\%) } \\
\hline & & $\mathrm{A} 1$ & A2 & A3 & B1 \\
\hline LLL & 42 & $6.40 \pm 0.35^{\mathrm{b}}$ & $5.91 \pm 0.01^{b}$ & $6.00 \pm 0.15^{b}$ & $12.6 \pm 0.20^{\mathrm{a}}$ \\
\hline LLO & 44 & $12.9 \pm 0.43^{\mathrm{b}}$ & $12.9 \pm 0.68^{b}$ & $11.6 \pm 0.03^{\mathrm{b}}$ & $20.7 \pm 0.14^{\mathrm{a}}$ \\
\hline PLL & 44 & $6.92 \pm 0.32^{\mathrm{b}}$ & $6.41 \pm 0.04^{\mathrm{b}}$ & $6.42 \pm 0.18^{\mathrm{b}}$ & $10.0 \pm 0.04^{\mathrm{a}}$ \\
\hline LOO & 46 & $14.1 \pm 0.11^{\mathrm{a}}$ & $14.9 \pm 0.98^{\mathrm{a}}$ & $14.7 \pm 0.44^{\mathrm{a}}$ & $14.1 \pm 0.05^{\mathrm{a}}$ \\
\hline PLO & 46 & $16.5 \pm 0.19^{\mathrm{a}}$ & $16.4 \pm 0.50^{\mathrm{a}}$ & $16.6 \pm 0.41^{\mathrm{a}}$ & $16.8 \pm 0.05^{\mathrm{a}}$ \\
\hline PPL & 46 & $2.51 \pm 0.34^{\mathrm{a}}$ & $1.33 \pm 0.26^{\mathrm{b}}$ & $1.92 \pm 0.21^{\mathrm{ab}}$ & $1.73 \pm 0.03^{\mathrm{ab}}$ \\
\hline $\mathrm{OOO}$ & 48 & $11.93 \pm 0.59^{\mathrm{a}}$ & $12.5 \pm 0.38^{\mathrm{a}}$ & $13.3 \pm 0.48^{\mathrm{a}}$ & $6.85 \pm 0.13^{\mathrm{b}}$ \\
\hline POO & 48 & $15.6 \pm 0.48^{\mathrm{b}}$ & $16.7 \pm 0.47^{\mathrm{a}^{\mathrm{b}}}$ & $17.4 \pm 0.39^{\mathrm{a}}$ & $10.9 \pm 0.21^{\mathrm{c}}$ \\
\hline PPO & 48 & $2.43 \pm 0.10^{\mathrm{ab}}$ & $1.52 \pm 0.18^{\mathrm{a}^{\mathrm{b}}}$ & $1.52 \pm 0.01^{\mathrm{b}}$ & $2.52 \pm 0.46^{\mathrm{a}}$ \\
\hline PPP & 48 & $1.91 \pm 0.08^{\mathrm{a}}$ & $1.81 \pm 0.41^{\mathrm{a}}$ & $1.91 \pm 0.24^{\mathrm{a}}$ & $0.60 \pm 0,01^{\mathrm{b}}$ \\
\hline SOO & 50 & $4.95 \pm 0.21^{\mathrm{a}}$ & $5.69 \pm 0.41^{\mathrm{a}}$ & $5.92 \pm 0.36^{\mathrm{a}}$ & $2.51 \pm 0.03^{\mathrm{b}}$ \\
\hline SSL & 50 & $2.74 \pm 0.05^{\mathrm{a}}$ & $2.91 \pm 0.44^{\mathrm{a}}$ & $2.50 \pm 0.41^{\mathrm{a}}$ & $0.92 \pm 0.01^{\mathrm{b}}$ \\
\hline sos & 52 & $0.64 \pm 0.02^{\mathrm{a}^{\mathrm{b}}}$ & $1.00 \pm 0.22^{\mathrm{a}}$ & $0.70 \pm 0.16^{\mathrm{a}^{\mathrm{b}}}$ & $0.31 \pm 0.01^{\mathrm{b}}$ \\
\hline
\end{tabular}

A1, A2, A3: sapucaia nuts from Piauí; B1: sapucaia nut from Minas Gerais. Mean \pm S.D. $(n=3)$. Different letters in the same line presented difference at a significant level (Tukey test, $p<0.05$ ). O: oleic acid; L: linoleic acid, P: palmitic acid; S: stearic acid. $\mathrm{ECN}=$ equivalent carbon number.

The chemical compounds identified in the sapucaia nut oil such as tocopherols, phytosterols, and oleic and linoleic acids when present in the diet can contribute to the maintenance of a healthy life. Studies have associated a nut rich diet to a reduced incidence of coronary heart diseases, and to other beneficial effects on hypertension, cancer, inflammation and cholesterol-lowering effect. The reported effects may be associated with a synergistic interaction of the many bioactive constituents of nuts (tocopherols, phytosterols, oleic and linoleic acids) which may all favorably influence human physiology (Aune et al., 2016; Cardoso et al., 2017; Nishi et al., 2014; Yang, 2009).

\subsection{Triacylglyceride (TAGs) profile of sapucaia oil}

The TAGs dilinoleo olein (LLO), palmito linoleo olein (PLO), linoleo diolein (LOO), palmito diolein (POO), triolein (OOO), palmito dilinoleo (PLL) and trilinoleo (LLL) were the major triacylglycerols in sapucaia

Table 6

Nutritional composition of sapucaia, Brazil and cashew nuts

\begin{tabular}{|c|c|c|c|}
\hline Parameter & Sapucaia nuts* & Brazil nuts & Cashew nuts \\
\hline Energy value $\left(\mathrm{kcal}^{\left.100 \mathrm{~g}^{-1}\right)}\right.$ & 534-617 & $643-710.6^{\mathrm{AB}}$ & $570-600.23^{\mathrm{AC}}$ \\
\hline Protein $\left({\left.\mathrm{g} 100 \mathrm{~g}^{-1}\right)}^{-1}\right.$ & $15.8-19.5$ & $14.5-18.58^{\mathrm{AB}}$ & $18.5-22.67^{\mathrm{AC}}$ \\
\hline Carbohydrate $\left(\mathrm{g}_{\left.100 \mathrm{~g}^{-1}\right)}\right.$ & $4.90-6.50$ & $7.60-15.1^{\mathrm{AB}}$ & $19.86-29.1^{\mathrm{AC}}$ \\
\hline $\begin{array}{l}\text { Total dietary fiber } \\
\qquad\left(\mathrm{g} 100 \mathrm{~g}^{-1}\right)\end{array}$ & $16.5-22.6$ & $7.9^{\mathrm{A}}$ & $3.7-3.92^{\mathrm{AC}}$ \\
\hline 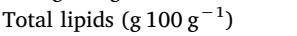 & $47.9-60.8$ & $63.5-67.20^{\mathrm{AB}}$ & $46.3-47.79^{\mathrm{AC}}$ \\
\hline $\mathrm{Ca}\left(\mu \mathrm{gg}^{-1}\right)$ & $1057-1249$ & $1460-1800^{\mathrm{AB}}$ & $330.0-640.5^{\mathrm{AC}}$ \\
\hline $\operatorname{Mg}\left(\mu g g^{-1}\right)$ & $1138-1740$ & $3250-3650^{\mathrm{AB}}$ & $2370-2770.0^{\mathrm{AC}}$ \\
\hline $\operatorname{Mn}\left(\mu g g^{-1}\right)$ & $22.9-41.4$ & $15.9-16.5^{\mathrm{AB}}$ & $11.0^{\mathrm{A}}$ \\
\hline $\mathrm{Zn}\left(\mu \mathrm{g} \mathrm{g}^{-1}\right)$ & $10.2-20.9$ & $35.1-42.0^{\mathrm{AB}}$ & $47.0-49.8^{\mathrm{AC}}$ \\
\hline $\mathrm{Cu}\left(\mu \mathrm{gg}^{-1}\right)$ & $7.00-16.9$ & $14.0-17.9^{\mathrm{AB}}$ & $19.2^{\mathrm{A}}$ \\
\hline Se $\left(\mu g g^{-1}\right)$ & $26.4-46.9$ & $11.48-36.1^{\mathrm{BE}}$ & $0.0102^{\mathrm{C}}$ \\
\hline $\begin{array}{l}\text { Total saturated fatty acids } \\
\quad\left(\mathrm{mg} 100 \mathrm{~g}^{-1}\right)\end{array}$ & $18.8-23.3$ & $24.5-26.7^{\mathrm{DE}}$ & $20.20-20.22^{\mathrm{DE}}$ \\
\hline 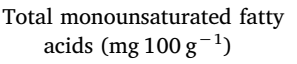 & $34.2-45.7$ & $29.97-38.6^{\mathrm{DE}}$ & $56.87-58.13^{\mathrm{DE}}$ \\
\hline $\begin{array}{l}\text { Total polyunsaturated fatty } \\
\left.\text { acids (mg } 100 \mathrm{~g}^{-1}\right)\end{array}$ & $32.7-47.0$ & $36.8-43.0^{\mathrm{DE}}$ & $21.03-22.22^{\mathrm{DE}}$ \\
\hline$\alpha$-Tocopherol (mg $100 \mathrm{~g}^{-1}$ ) & $0.75-2.24$ & $5.44-8.29^{\mathrm{DE}}$ & $0.36-1.48^{\mathrm{DE}}$ \\
\hline$\gamma$-Tocopherol (mg $\left.100 \mathrm{~g}^{-1}\right)$ & $19.2-28.5$ & $11.62-14.63^{\mathrm{DE}}$ & $5.56-5.72^{\mathrm{DE}}$ \\
\hline$\beta$-sitosterol (mg $\left.100 \mathrm{~g}^{-1}\right)$ & $92.8-194$ & $62.7-132.54^{\mathrm{DE}}$ & $111.0-176.8^{\mathrm{DE}}$ \\
\hline Stigmasterol (mg $\left.100 \mathrm{~g}^{-1}\right)$ & $9.92-13.2$ & $5.5-5.7^{\mathrm{DE}}$ & $0.7-11.67^{\mathrm{DE}}$ \\
\hline Campesterol $\left(\mathrm{mg} 100 \mathrm{~g}^{-1}\right)$ & $8.42-9.63$ & $1.2-2.69^{\mathrm{DE}}$ & $8.6-10.53^{\mathrm{DE}}$ \\
\hline
\end{tabular}

* Samples of sapucaia nuts from Piauí and Minas Gerais (A1, A2, A3 and B1). ${ }^{\mathrm{A}}$ TACO (2011), ${ }^{\text {B }}$ Santos et al. (2013), ${ }^{C_{S}}$ Sousa, Fernandes, Alves, Freitas, and Naves (2011), ${ }^{\text {DYyang }}$ (2009), ${ }^{\mathrm{E}}$ Robbins et al. (2011). nut oil (Table 5). The triacylglycerols found in sapucaia nut oil predominantly contained oleic and linoleic acids and less palmitic and stearic acids, which is compatible with the fatty acid profile found in the samples. The TAG composition of the sapucaia nut oil obtained in this study is similar to results reported by Teixeira et al. (2018).

\subsection{Nutritional composition and lipid profile of the sapucaia nut compared with Brazil nut and cashew}

The Brazil nut and cashew are nuts native from Brazil and known worldwide as foods rich in bioactive compounds. The sapucaia nut, despite its significant nutritional potential, is still an underutilized food material. Table 6 shows that the sapucaia nut presents a lower content of oil than Brazil nut and higher than cashew nut. On the other hand, the protein content is similar to Brazil nuts and cashew nuts. The dietary fiber content of the sapucaia nut is higher than that reported in the literature for Brazil nuts and cashew nuts.

Sapucaia and Brazil nuts are rich in Se. In sapucaia nuts, the content of $\mathrm{Ca}$ is higher than cashew nuts and lower than Brazil nuts. The content of $\mathrm{Mg}$ and $\mathrm{Zn}$ are higher in Brazil and cashew nuts when compared with sapucaia nuts. On the other hand, the Mn content is higher in sapucaia nut when compared to Brazil and cashew nuts and the $\mathrm{Cu}$ content is similar for all nuts.

The sapucaia nut presents a lower concentration of saturated fatty acids than Brazil nuts and cashew nuts. The content of monounsaturated and polyunsaturated fatty acids of the sapucaia nut are similar to Brazil nuts. On the other hand cashew nuts have a higher content of monounsaturated fatty acids and lower for polyunsaturated fatty acids when compared to the sapucaia nut. The sapucaia nut presents higher content of $\gamma$-tocopherol when compared to Brazil nuts and cashews nuts.

These results showed that sapucaia nuts presents potential health benefits and may be used to improve the diet of the Brazilian population. Its nutritional and phytochemical composition is comparable and, in some cases, better than other representative Brazilian native nuts such as Brazil nuts and cashews.

\section{Conclusions}

The evaluation of the nutritional composition and lipid profile of sapucaia nut and its by-products showed a significant nutritional potential for these raw materials. Significant differences were observed for the nutritional composition of the sapucaia nuts, cakes and shells between samples obtained from different regions. This underutilized nut present desirable nutritional and phytochemical composition, comparable to other representative native Brazil nuts. The high protein, dietary fiber and minerals in sapucaia nut and cake indicated that this raw material may be used as a nutrient-rich ingredient in different applications. The selenium content may limit the direct consumption of the nuts but, on the other hand, the ingestion of Se in regions of high $\mathrm{Hg}$ exposure may be important because of the protective effect of Se against $\mathrm{Hg}$. As the sapucaia nut oil is an excellent source of bioactive compounds, such as oleic and linoleic acids, $\gamma$-tocopherol and $\beta$-sitosterol, it may contribute to the maintenance of human health. The results of this work represent a step forward for knowledge of this underutilized raw material. The data obtained may be used to stimulate the local production and consumption of this type of nut, leading to its economic development. In addition, the nuts may be used as a promising raw material for the food industry.

\section{Conflict of interest}

The authors confirm that there are no conflicts of interest associated with this publication. 


\section{Acknowledgments}

The authors would like to thank Letícia Turcatto for their assistance in the analyses. The authors also would like to thank Eduardo Euclydes de Lima e Borges from Federal University of Viçosa for providing the sapucaia nuts from Viçosa (Minas Gerais), and Professor Gianluca Li Puma from University of Loughborough for reviewing the English language of this manuscript. Authors are gratefulto Coordenação de Aperfeiçoamento de Pessoal de Nível Superior (CAPES) for awarding a scholarship for Fernanda Demoliner.

\section{Appendix A. Supplementary data}

Supplementary data to this article can be found online at https:// doi.org/10.1016/j.foodres.2018.03.028.

\section{References}

AOAC - Association of Official Analytical Chemists (2005). Official methods of analysis of the AOAC (18th ed.). Arlington, VA: AOAC (2005).

AOCS - American Oil Chemists Society (2004). Official methods and recommended practices of the AOCS (5th ed.). Champaign, IL: AOCS2004.

ATSDR - Agency for Toxic Substances and Disease Registry (2017). Minimal risk levels (MRLs) for hazardous substances. Available from http://www.atsdr.cdc.gov/mrls/ mrllist.asp\#64tag, Accessed date: 10 July 2017.

Aune, D., Keum, N., Giovannucci, E., Fadnes, L. T., Boffetta, P., Greenwood, D. C., Norat, T. (2016). Nut consumption and risk of cardiovascular disease, total cancer, all-cause and cause-specific mortality: A systematic review and dose-response metaanalysis of prospective studies. BMC Medicine, 14, 207.

Bragagnolo, N., \& Rodriguez-Amaya, D. B. (1993). Comparative evaluation of three methods for determination of cholesterol in egg yolk. Brazilian Archives of Biology and Technology, 36, 237-251.

Brazil (2005). National Health Surveillance Agency (ANVISA - Agência Nacional de Vigilância Sanitária). Resolução $R D C n^{\circ} 270$, de 22 de setembro de 2005. Regulamento técnico para óleos vegetais, gorduras vegetais e creme vegetalBrasília: Diário Oficial da Uniãohttp://www.oliva.org.br/wp-content/uploads/2016/11/resolucao-rdc-n27022-09-2005.pdf 2005, Accessed 23 July 2017.

Cardoso, B. R., Duarte, G. B. S., Reis, B. Z., \& Cozzolino, S. M. F. (2017). Brazil nuts: Nutritional composition, health benefits and safety aspects. Food Research International, 100, 9-18.

Carvalho, I. M. M., Queirós, L. D., Brito, L. F., Santos, F. A., Bandeira, A. V. M., de Souza, A. L., \& de Queiroz, J. H. (2012). Chemical characterization of sapucaia nuts (Lecythis pisonis Cambess.) from zona da mata mineira region. Bioscience Journal, 28, 971-977.

Carvalho, M. G., Costa, J. M. C., Souza, V. A. B., \& Maia, G. A. (2008). Evaluation of some physical and nutritional parameters of almonds of chichá, sapucaia and castanha-dogurguéia. Revista Ciência Agronômica, 39, 517-523.

Castelo-Branco, V. N., Santana, I., Di-Sarli, V. O., Freitas, S. P., \& Torres, A. G. (2016). Antioxidant capacity is a surrogate measure of the quality and stability of vegetable oils. European Journal of Lipid Science and Tecnology, 118, 224-235.

Codex Alimentarius Comission (1996). General standard for contaminants and toxins in foods. 1996. Rome: FAO/WHO.

Colpo, E., Dalton, D. A. V. C., Reetz, L. G., Duarte, M. M., Farias, I. L., Meinerz, D. F., ... da Rocha, J. B. (2014). Brazilian nut consumption by healthy volunteers improves inflammatory parameters. Nutrition, 30, 459-465.

Costa, T., \& Jorge, N. (2012). Characterization and fatty acids profile of the oils from Amazon nuts and walnuts: Characterization and fatty acids profile of the oil seeds. Nutrition and Food Science, 42, 279-287.

Denadai, S. M. S., Hiane, P. A., Marangoni, S., Baldasso, P. A., Miguel, A. M. R. O., \& Macedo, M. L. R. (2007). In vitro digestibility of globulins from sapucaia (Lecythis pisonis Camb.) nuts by mammalian digestive proteinases. Food Science and Technology, 27, 535-543.

Desai, A. J., Dong, M., \& Miller, L. J. (2016). Beneficial effects of $\beta$-sitosterol on type 1 cholecystokinin receptor dysfunction induced by elevated membrane cholesterol. Clinical Nutrition, 35, 1374-1379.

FAO/WHO (2001). Human vitamin and mineral requirements. Report of a joint FAO/WHO expert consultation Bangkok, Thailand (pp. 151-270). .

Fardellone, P. (2015). Calcium, magnesium and natural mineral waters. Cahiers de Nutrition at de Diététique, 55, 22-29.

Food and Nutrition Board (2004). Dietary Reference Intake (DRIs): Recommended intakes for individuals elements. Institute of Medicine, National Academies Press.

Hartman, L., \& Lago, R. C. A. (1973). Rapid preparation of fatty acids methyl esters. Laboratory Practice, London, 22, 475-476.

Jiang, Q. (2014). Natural forms of vitamin E: Metabolism, antioxidant, and anti-inflammatory activities and their role in disease prevention and therapy. Free Radical Biology and Medicine, 72, 76-90.

Kumar, B. S., \& Priyadarsini, K. I. (2014). Selenium nutrition: How important is it? Biomedicine \& Preventive Nutrition, 4, 333-341.
Lemire, M., Fillion, M., Barbosa, F., Jr., Guimarães, J. R. D., \& Mergler, D. (2010). Elevated levels of selenium in the typical diet of Amazonian riverside populations. Science of the Total Environment, 408, 4076-4084.

Naozuka, J., Vieira, E. C., Nascimento, A. N., \& Oliveira, P. V. (2011). Elemental analysis of nuts and seeds by axially viewed ICP OES. Food Chemistry, 124, 1667-1672.

Ndanuko, R. N., Tapsell, L. C., Charlton, K. E., Neale, E. P., O'Donnell, K. M., \& Batterham, M. J. (2017). Relationship between sodium and potassium intake and blood pressure in a sample of overweight adults. Nutrition, 33, 285-290.

Nielsen, F. H. (2014). Should bioactive trace elements not recognized as essential, but with beneficial health effects, have intake recommendations. Journal of Trace Elements in Medicine and Biology, 28, 406-408.

Nishi, S. K., Kendall, C. W. C., Bazinet, R. P., Bashyam, B., Ireland, C. A., Augustin, L. S A., ... Jenkins, D. J. A. (2014). Nut consumption, serum fatty acid profile and estimated coronary heart disease risk in type 2 diabetes. Nutrition, Metabolism, and Cardiovascular Diseases, 24, 845-852.

Panfili, G., Fratianni, A., \& Irano, M. (2003). Normal phase high-performance liquid chromatography method for the determination of tocopherols and tocotrienols in cereals. Journal Agriculture Food Chemistry, 51, 3940-3944.

Parmalee, N. L., \& Aschner, M. (2016). Manganese and aging. Neurobehavioral Toxicology, $56,262-268$.

Rabadán, A., Álvarez-Ortí, M., Gómez, R., Alvarruiz, A., \& Pardo, J. E. (2017). Optimization of pistachio oil extraction regarding processing parameters of screw and hydraulic presses. LWT- Food Science and Technology, 83, 79-85.

Robbins, K. S., Shin, E.-C., Shewfelt, R. L., Eitenmiller, R. R., \& Pegg, R. B. (2011). Update on the healthful lipid constituents of commercially important tree nuts. Journal of Agricultural and Food Chemistry, 59, 12083-12092.

Roman, M., Jitaru, P., \& Barbante, C. (2014). Seleniun biochemistry and its role for human health. Metallomics, 6, 25-54.

Sakamoto, M., Yasutake, A., Kakita, A., Ryufuku, M., Chan, H. M., Yamamoto, M., Watanabe, C. (2013). Selenomethionine protects against neuronal degeneration by methyl mercury in the developing rat cerebrum. Environmental Science \& Technology, $47,2862-2868$.

Salas-Salvadó, J., Bulló, M., Pérez-Heras, A., \& Ros, E. (2006). Dietary fiber, nuts and cardiovascular diseases. The British Journal of Nutrition, 96, 46-51.

Santos, O. V., Corrêa, N. C. F., Carvalho, R. N., Jr., Costa, C. E. F., França, L. F. F., \& Lannes, S. C. S. (2013). Comparative parameters of the nutritional contribution and functional claims of Brazil nut kernels, oil and defatted cake. Food Research International, 51, 841-847.

Scheiber, I. F., Mercer, J. F. B., \& Dringen, R. (2014). Metabolism and functions of copper in brain. Progress in Neurobiology, 16, 33-57.

Segura, N., Silva, R. C., Soares, F. A. S. M., Gioielli, L. A., \& Jachmanián, I. (2011) Valorization of beef tallow by lipase-catalyzed interesterification with high oleic sunflower oil. Journal of the American Oil Chemists' Society, 88, 1945-1954.

Shahzad, N., Khan, W., Ali, A., Saluja, S. S., Sharma, S., Al-Allaf, F., ... Al-Ghamdi, S. S. (2017). Phytosterols as a natural anticancer agent: Current status and future perspective. Biomedicine \& Pharmacotherapy, 88, 786-794.

Silva Júnior, E. C., Wadt, L. H. O., Silva, K. E., Lima, R. M. B., Batista, K. D., Guedes, M. C., Guilherme, L. R. G. (2017). Natural variation of selenium in Brazil nuts and soils from the Amazon region. Chemosphere, 188, 650-658.

Sousa, A. G., Fernandes, D. C., Alves, A. M., Freitas, J. B., \& Naves, M. M. V. (2011). Nutritional quality and protein value of exotic almonds and nut from the Brazilian Savanna compared to peanut. Food Research International, 44, 2319-2325.

TACO - Tabela Brasileira de Composição de Alimentos (2011). Unicamp (4th ed.). www. unicamp.br/nepa/taco, Accessed date: 23 August 2017.

Teixeira, G. L., Ávila, S., Ribani, M., Silveira, J. L. M., \& Ribani, R. H. (2017). Chemical, thermal and rheological properties and stability of sapucaia (Lecythis pisonis) nut oils: A potential source of vegetable oil in industry. Journal of Thermal Analysis and Calorimetry, 131, 2105-2121.

Teixeira, G. L., Ghazani, S. M., Corazza, M. L., Marangoni, A. G., \& Ribani, R. H. (2018). Assessment of subcritical propane, supercritical $\mathrm{CO}_{2}$ and Soxhlet extraction of oil from sapucaia (Lecythis pisonis) nuts. The Journal of Supercritical Fluids, 133, 122-132.

USDA - United States Department of Agriculture (2017). Agricultural research service ARS, National Genetic Resources Program. Germplasm resources information network (GRIN). Beltsville, Maryland: National Germplasm Resources Laboratory. https:// npgsweb.ars-grin.gov/gringlobal/taxonomydetail.aspx?id=21714, Accessed date: 6 January 2018.

Vallilo, M. I., Tavares, M., Aued-Pimentel, S., Campos, N. C., \& Moita Neto, J. M. (1999). Lecythis pisonis Camb. nuts: Oil characterization, fatty acids and minerals. Food Chemistry, 66, 197-200.

Wani, A. L., Parveen, N., Ansari, M. O., Ahmad, M. F., Jameel, S., \& Shadab, G. G. H. A. (2017). Zinc: An element of extensive medical importance. Current Medicine Research and Practice, 7, 90-98.

Wickens, G. E. (1995). Edible nuts. Roma: FAO. (Non wood Forest products, 5). Rome: Food and Agriculture Organization of the United Nations69-71.

Yada, S., Huang, G., \& Lapsley, K. (2013). Natural variability in the nutrient composition of California-grown almonds. Journal of Food Composition and Analysis, 30, 80-85.

Yang, J. (2009). Brazil nuts and associated health benefits: A review. LWT-Food Science and Technology, 42, 1573-1580.

Zang, C., Wang, X., Ashraf, U., Qiu, B., \& Ali, S. (2017). Transfer of lead (Pb) in the soil plant-mealybug-ladybird beetle food chain, a comparison between two host plants. Ecotoxicology and Environmental Safety, 143, 289-295. 